\title{
Physiological and Growth Responses in the (Schizolobium amazonicum Huber ex Ducke) Seedlings Subjected to Cadmium Doses
}

\author{
Glauco A. S. Nogueira ${ }^{1}$, Ana E. A. Brito ${ }^{1}$, Vitor R. Nascimento ${ }^{1}$, Gerson D. P. Albuquerque ${ }^{1}$, \\ Anderson S. Botelho ${ }^{2}$, Luma C. Souza ${ }^{1}$, Joze M. N. Freitas ${ }^{1}$, Cristine B. Amarante ${ }^{2}$, Ricardo S. Okumura ${ }^{1}$, \\ Heráclito E. O. Conceição ${ }^{1}$, Rafael G. Viana ${ }^{1} \&$ Cândido F. Oliveira Neto ${ }^{1}$ \\ ${ }^{1}$ Institute of Agrarian Sciences, Universidade Federal Rural da Amazônia, Brazil \\ ${ }^{2}$ Museu Paraense Emílio Goeldi, Brazil \\ Correspondence: Glauco A. S. Nogueira, Institute of Agrarian Sciences, Universidade Federal Rural da \\ Amazônia, Avenida Presidente Tancredo Neves, № 2501 Bairro, Terra Firme, Cidade, Belém, Pará, Brazil. Tel: \\ 55-219-99-044-368. E-mail: glauand@yahoo.com.br
}

Received: November 23, 2018

Accepted: April 7, 2019 Online Published: June 15, 2019

doi:10.5539/jas.v11n8p217

URL: https://doi.org/10.5539/jas.v11n8p217

\begin{abstract}
The aim of this work was to evaluate, by the physiological and growth variables, the behavior of paricá seedlings submitted to cadmium aplications. Cadmium is a importante metal due the industrial use, the accumulation in the environment, the high mobility in the soil-plant system, and possibly by changing physiological and growth parameters in plants. Among the plants that can be affected by this metal is the species (Schizolobium amazonicum Huber ex Ducke), known as paricá. Native from the amazona region, presents great social, economic and environmental potential. Among the physiological variables analyzed, cadmium interfered with photosynthesis, stomatal conductance and transpiration, mainly with the increase of the concentrations of this element. Among the correlated variables, the variable intrinsic efficiency of water use (EiUA), presented high in the stress conditions maintaining the minimum of water balance. For the growth variables, the cadmium provided a decrease in the height, diameter, number of leaves and leaflets influencing the low synthesis of photoassimilates. The phytotoxic element was mainly concentrated in the roots, but there was translocation to shoot, signaling a phytoextractive characteristic.
\end{abstract}

Keywords: biophysical variables, paricá, physiological, trace element

\section{Introduction}

The toxicity of heavy metals depends on their concentration and bioavailability in the soil, on the time of exposure to the element, as well as on plant genotype and overall conditions. In addition, the dose-response, i.e., the concentration that leads to a specific effect, varies between essential and non-essential elements (Almeida, 2015).

Cadmium is a non-essential element to plants because it does not have a metabolic function (Ok et al., 2011) and is extremely toxic to different organisms, even at soil concentrations lower than $10 \mathrm{mg} \mathrm{kg}^{-1}$; which is enough to trigger significant effects on plant growth. Among the most common cadmium toxicity effects on plants are decreased plant growth, mainly root growth due to mineral deficiency (Shah et al., 2001; Vitória et al., 2001; Fornazier et al., 2002), reduced biomass production (Knecht et al., 1994; Soltan \& Rashed, 2003; Benavides et al., 2005), photosynthetic apparatus destabilization (Qian et al., 2010), as well as changes in stomatal conductance and leaf transpiration (Souza et al., 2011).

It is essential to know the growth and tolerance mechanisms of plants against this trace element due to its increasing concentration in agricultural soils, mainly due to the use of phosphate fertilizers, which are one of the most important Cd contamination sources in agriculture (François, 2009; Grant, 2011; Ferreira, 2013). This knowledge is also essential to enable food production and well as maintaining environmental health health at, since cadmium is a potential agricultural hazard (Römkens, 2011).

As a result, the aim of the current study is to evaluate the behavior of paricá seedlings subjected to increasing cadmium concentrations based on ecophysiological and growth variables. 


\section{Materials and Methods}

\subsection{Experimental Condition and Plant Material}

The experiment was conducted in the greenhouse of the Agricultural Sciences Institute (ICA-Instituto de Ciências Agrárias), Federal Rural University of Amazonia (UFRA-Universidade Federal Rural da Amazônia),

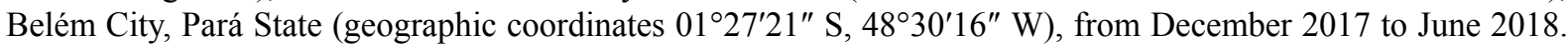
Paricá seeds provided by Pará State Association of Timber Exporter Industries (AIMEX-Associação das Indústrias Exportadoras de Madeira do Estado do Pará) were used in the experiment.

\subsection{Seedling Production and Plant Exposure to Cadmium Doses}

The paricá seedling production process was conducted as follows: seeds were scarified with sandpaper (\#80) and placed in cold water for 24 hours to make dormancy breaking easier. Next, seeds were placed in 4.6 L Leonard jars (adapted with polyethylene clamps) filled with washed and autoclaved sand; the jars were wrapped with aluminum foil to minimize the interference of solar radiation on root growth. Circular-shaped EVA paper was placed on the surface of each jar to avoid algae proliferation. Two months later, cadmium chloride concentrations $\left(\mathrm{CdCl}_{2} \cdot \mathrm{H}_{2} \mathrm{O}\right)$ in nutrient solution were applied to the seeds. Solutions were renewed on a weekly basis and $\mathrm{pH}$ was kept between 5.8 to 6.0 through the addition of $0.1 \mathrm{~mol} \mathrm{~L}^{-1}$ of $\mathrm{NaOH}$ or $\mathrm{HCl}$, whenever adjustments were needed.

\subsection{Ecophysiological Variables}

Plants showing cadmium toxicity signs were collected and subjected to physiological and growth analyses. Liquid photosynthetic $(A)$, stomatal conductance $(g s)$ and transpiration $(E)$ rates were measured in the IRGA portable meter (Infra-red Gas Analyzer/ADC equipment-model LCi 6400, Hoddesdon, UK) under favorable environmental conditions, between 9:00 a.m. and 11:00 a.m. One leaflet per plant (always the median region of the fully expanded leaf) was inserted in the equipment chamber in order to measure these variables. Next, the $\mathrm{Ci} / \mathrm{Ca}$ ratio, instantaneous carboxylation efficiency (iCE), water use efficiency (WUE) and intrinsic water use efficiency (iWUE) were quantified.

\subsection{Determining Chlorophyll $a, b$, Total $(a+b)$ and Anthocyanin Contents}

Based on the method adopted to measure these variables (Sims \& Gamon, 2002), $100 \mathrm{mg}$ of fresh leaf from each sample was weighed, placed in a mortar containing $3 \mathrm{ml}$ of $80 \%$ acetone, macerated and filtered through paper towels. The supernatant was transferred to a $25 \mathrm{~mL}$ volumetric flask and its volume was measured using $80 \%$ acetone. Samples were read in spectrophotometer at $663 \mathrm{~nm}$ (Chlorophyll A), $647 \mathrm{~nm}$ (Chlorophyll B), $537 \mathrm{~nm}$ (Anthocyanins) by previously placing the blank to reset the apparatus (acetone $80 \%$ ). Total chlorophyll content was calculated as follows: Total chlorophyll $=$ chlorophyll $\mathrm{a}+$ chlorophyll $\mathrm{b}$. All the extraction process was performed on ice and in the dark.

\subsection{Growth Variables}

Growth parameters were determined through measurements conducted at the end of the experimental period and resulted in the following variables:

(1) Plant height: measured from the surface of the soil to the apex of the plant, with a millimeter ruler. Results were expressed in $\mathrm{cm}$.

(2) Collar diameter: measured with a $200 \mathrm{~mm}$ digital caliper (Digimes). Results were expressed in $\mathrm{mm}$.

(3) Number of leaves: the number of living leaves was counted.

(4) Number of leaflets: the number of living leaflets was counted.

\subsection{Experimental Design and Statistical Analysis}

The experimental design was completely randomized (CRD), with 5 treatments comprising control plants (cadmium-free) and plants threated with cadmium doses $\left(\mathrm{CdCl}_{2} 178 \mu \mathrm{M} ; \mathrm{CdCl}_{2} 356 \mu \mathrm{M} ; \mathrm{CdCl}_{2} 534 \mu \mathrm{M} ; \mathrm{CdCl}_{2}\right.$ $712 \mu \mathrm{M}$ ), with 7 repetitions each (one plant/jar) - 35 experimental units, in total.

Data were subjected to analysis of variance in the F test $(p<0.05)$; means were compared to each other through the least significant difference in the Tukey test $(\mathrm{p}<0.05)$ and adjusted through polynomial regression equations $(\mathrm{P}<0.01$ or 0.05$)$ in the Sisvar software (Ferreira, 2011). 


\section{Results and Discussion}

\subsection{Physiological Variables}

\subsubsection{Photosynthesis}

Based on our results, the photosynthesis of paricá seedlings decreased considerably as the cadmium doses increased; there was a statistically significant difference between the photosynthesis of these seedlings and that of the control plants. The relative percentage decrease and increase (RPDI) was quite high: it reached $-76 \%$ decrease (Table 1). This characteristic can be a sensitive stress indicator caused by cadmium. Cadmium effects on photosynthesis lie on blocking energy dissipation in the form of heat (ATP), which prevents energy from being absorbed in the reaction centers of photosystem II. According to Parmar et al. (2014), it happens due to thylakoid destructuring, which reduces the photochemical efficiency of these photosynthetically active membranes. Another probable explanation for this result lies on the direct inhibition of chlorophyll synthesis or on restrictions in $\mathrm{Mg}$ absorption and translocation, since the magnesium found in chloroplasts works as protector by inhibiting the action of cadmium and preventing the transport of electrons (Benavides et al., 2005; Martins et al., 2013, Zhang et al., 2014).

\subsubsection{Stomatal Conductance (gs)}

Stomatal conductance decreased considerably as the cadmium doses increased. However, statistically significant differences were only recorded for treatments $\mathrm{T} 3(356 \mu \mathrm{M}), \mathrm{T} 4(534 \mu \mathrm{M})$ and $\mathrm{T} 5(712 \mu \mathrm{M})$ in comparison to the control. The relative percentage decrease and increase (RPDI) was higher than $-70 \%$ decrease (Table 1); this outcome showed to what extent the stomatal conductance changed. $\mathrm{Cd}$ decreased the partial $\mathrm{CO}_{2}$ pressure in the stomata by decreasing the carbon dioxide concentration and the stomatal conductance, which led to stomatal closure and to decreased transpiration, besides affecting Rubisco activity (Hasanuzzaman et al., 2013). One of the harmful effects of cadmium lies on inducing calcium production in the endoplasmic reticulum and in the vacuole. This production increases the levels of this cation in the cytosol, which is associated with stomatal closure (Perfus-barbeoch et al., 2002).

\subsubsection{Transpiration (E)}

Transpiration results were similar to the ones recorded for photosynthesis and stomatal conductance, since these variables were directly correlated to each other. The sharp decrease in transpiration reached relative percentage decrease and increase (PRDI) values such as $54.75 \%$, which enabled statistically significant differences between the major cadmium treatments-T4 $(534 \mu \mathrm{M})$ and T5 $(712 \mu \mathrm{M})$ and the control (Table 1).

According to Leita et al. (1995), Cd affects stomatal opening and closing: firstly, due to increase in the osmotic potential of the leaves; secondly, due to direct $\mathrm{Cd}$ action on guard cells, as well as to root growth inhibition, which limits water absorption and leads to stomatal closure. In addition, high $\mathrm{Cd}$ concentrations lead to metabolic decline, leaf turgidity loss and hydropassive stomatal closure.

\subsubsection{Water Use efficiency (WUE)}

According to Zhao (2004), in physiological terms, water use efficiency (WUE) is defined as the ratio between carbon fixation (photosynthesis) and transpiration rates $(A / E)$. Thus, based on the herein analyzed ratio, water use efficiency decreased as cadmium concentrations increased. There was statistically significant difference in water use efficiency between cadmium-treated and control plants. The relative percentage decrease and increase recorded for this variable was higher than $-45 \%$ (Table 1). This outcome corroborates the study by Lefévre et al. (2014), who stated that the stress caused by heavy metals leads to lower water use efficiency.

This result indicate low $\mathrm{CO}_{2}$ fixation, since this parameter determines the species' effectiveness in fixing carbon during transpiration. The phytotoxic element accumulated in the root system directly affected the growth of this organ, which may have led to low water absorption and changed the conducting vessels' anatomy, which directly affected the water transport process (Bacelar et al., 2007).

\subsubsection{Instantaneous Carboxylation Efficiency (iCE)}

The iCE results herein recorded for $\mathrm{A} / \mathrm{Ci}$ ratio showed decrease in this variable, as well as statistically significant differences between cadmium-treated and control plants; the relative percentage decrease and increase (RPDI) recorded $-76.66 \%$ decrease, as shown in Table 1 . The instantaneous carboxylation efficiency depends on $\mathrm{CO}_{2}$ availability in the leaf mesophyll, on the amount of light, on temperature and on enzyme activity to enable photosynthesis. The stomatal opening significantly decreased in the current study and it influenced the intercellular $\mathrm{CO}_{2}$ concentrations, which became very low. The influx of this component in mesophyll cells was 
restricted; thus, the plant used $\mathrm{CO}_{2}$ resulting from the breathing process to keep the photosynthetic rate at minimum level, thus making it limited (Taiz \& Zeiger, 2009b).

\subsubsection{Intrinsic Water Use Efficiency (iWUE)}

The iWUE was calculated by dividing $(A / g s)$. Based on results of intrinsic water use efficiency (iWUE), the internal water use efficiency of plants subjected to cadmium-induced stress increased as the metal doses increased. There was statistically significant difference between cadmium-treated and control plants in T2 (178 $\mu \mathrm{M}$ ), only. The relative percentage decrease and increase (RPDI) was above $-45 \%$ decrease, according to Table 1 . High iWUE is a characteristic of plants that try to tolerate stressful conditions such as low water availability caused by high cadmium concentrations (Ma et al., 2004). According to the aforementioned authors, high photosynthetic rates and low stomatal conductance $(g s)$ values partly explain the iWUE increase.

\subsubsection{Internal $\mathrm{CO}_{2}$ Concentration and Environment $(\mathrm{Ci} / \mathrm{Ca})$}

Internal and external carbon ratios increased in the first two cadmium-stress treatments-T2 $(178 \mu \mathrm{M})$ and T3 $(356 \mu \mathrm{M})$; they decreased in $\mathrm{T} 4(534 \mu \mathrm{M})$ and increased again in T5 $(712 \mu \mathrm{M})$. T2 $(178 \mu \mathrm{M})$ and T4 $(534 \mu \mathrm{M})$ showed statistically significant differences in comparison to the control group. The relative percentage decrease and increase (RPDI) was low $-11 \%$ (Table 1).

The activity of enzymes involved in $\mathrm{CO}_{2}$ fixation may have been affected and it increased the $\mathrm{Ci} / \mathrm{Ca}$ values in the first two treatments. The reduced transpiration in plants subjected to cadmium stress can be associated with cuticle and stomata destruction, and with leaf limb rupture, which decreased $g s$ and affected the $\mathrm{Ci} / \mathrm{Ca}$ ratio (Guerra et al., 2014).

\section{Biochemical Evaluations: Pigment Content}

\subsection{Chlorophyll $a, b$ and Total}

Chlorophyll $a$ contents in plants subjected to heavy metal stress decreased in comparison to control plants; the lowest chlorophyll $a$ value in cadmium-treated plants was found in T3 $(356 \mu \mathrm{M})$, whereas the highest value was recorded for plants in T5 $(712 \mu \mathrm{M})$. T2 $(178 \mu \mathrm{M})$, T3 $(356 \mu \mathrm{M})$ and T4 $(534 \mu \mathrm{M})$ showed statistically significant difference in comparison to control plants. Chlorophyll $a$ recorded RPDI -33.4\% (Table 1).

Chlorophyll $b$ contents decreased until T4 $(534 \mu \mathrm{M})$; plants subjected to different cadmium stress conditions did not show statistically significant difference in Chlorophyll $b$ content between treatments; however, there was statistically significant difference between cadmium-treated and control plants. The relative percentage decrease and increase (RPDI) was $-37.26 \%$ higher than that of chlorophyll $a$. Chlorophyll contents overall decreased at some points, whereas in others, they adjusted to cadmium concentrations (Table 1).

Total $(\mathrm{a}+\mathrm{b})$ chlorophyll content decreased in plants subjected to heavy metal stress, which showed statistically significant differences in comparison to control plants; the lowest total chlorophyll value was found in T3 (356 $\mu \mathrm{M}$ ). The relative percentage decrease and increase (PRA) of total chlorophyll was $-36.45 \%$ (Table 1 ). This value confirmed the change in chlorophyll functions.

There was chlorophyll degradation in plants subjected to cadmium stress and, consequently, their photosynthetic process was inhibited due to exposure to $\mathrm{Cd}$. However, high $\mathrm{Cd}$ concentrations are necessary to enable finding effects on the photosynthetic system of most species (Ekmekci et al., 2008; Redondo-Goméz et al., 2010; Roychoudhury et al., 2012; Martins et al., 2013), as observed in the current study when high Cd doses were applied to plants. Chlorophyll degradation takes place due to $\mathrm{Mg}$ replacement in chlorophyll molecules and to $\mathrm{Fe}$ replacement in the cytochromes of proteins involved in the photosynthesis process (Taiz \& Zeiger, 2002a; DalCorso et al., 2008; Marques \& Nascimento, 2013).

$\mathrm{Mg}$ is a structural part of the tetrapyrrole nucleus of chlorophyll molecules, but it also plays a specific role in the activation of enzymes involved in photosynthesis. Lack of Mg leads to chlorosis between leaf ribs; chlorosis can be first seen in older leaves due to Mg mobility (Taiz \& Zeiger, 2002a). Fe plays a key role as a component of protein complexes (ferredoxins) involved in transfer of electrons in the luminous phase of photosynthesis. Both $\mathrm{Mg}$ and Fe deficiencies trigger a characteristic symptom, i.e., chlorosis between leaf ribs. Unlike Mg, chlorosis resulting from $\mathrm{Fe}$ deficiency initially appears in younger leaves because iron cannot be readily mobilized from the older leaves (Taiz \& Zeiger, 2002a). According to DalCorso et al. (2008), chlorosis can result from changes in the $\mathrm{Fe} / \mathrm{Zn}$ ratio, as well as from negative $\mathrm{Cd}$ effects on chlorophyll metabolism.

\subsection{Anthocyanin}

Anthocyanin levels in cadmium-treated plants overall decreased in comparison to the control; there was statistically significant differences between treatments T2 $(178 \mu \mathrm{M})$, T3 $(356 \mu \mathrm{M})$ and $\mathrm{T} 4(534 \mu \mathrm{M})$ and the 
control group. The relative percentage decrease and increase (RPDI) of anthocyanin levels was $-24.51 \%$ (Table 1). The comparison between cadmium-stress treatments recorded increased anthocyanin levels. According to Keilig and Ludwig-Müller (2009), Michalak (2006), and Singh et al. (2013), this response is expected in plants grown in the presence of heavy metals at problematic levels; these plants produce secondary metabolites such as flavonoids and anthocyanin in order to eliminate reactive oxygen compounds formed by metals such as cadmium.

\section{Biophysical Variables}

\subsection{Height}

Despite the brief time paricá plants remained exposed to cádmio, their growth was negatively affected by it, as seen in the relative percentage decrease and increase (RPDI) value (14.17\%), which indicated the phytotoxicity of the species. Height is a growth parameter that shows the ability of plants to respond to the influence of biotic and abiotic factors affecting their metabolism and development (Taiz \& Zeiger, 2013c). There were statistically significant differences in height between cadmium-treated and control plants (Table 1).

\subsection{Collar Diameter}

Collar diameter decreased as the cadmium doses increased. There were statistically significant differences between treatments T2 $(178 \mu \mathrm{M}), \mathrm{T} 3(356 \mu \mathrm{M})$ and T4 $(534 \mu \mathrm{M})$ and the control plants; the relative percentage decrease and increase (RPDI) value recorded $-14.41 \%$ decrease. This outcome showed the negative influence of this heavy metal on plant growth. According to Ekmekçia et al. (2008), decreased chlorophyll contents are strongly associated with decreased plant height and diameter, as well as with changes in overall plant growth, mainly due to lower photoassimilate synthesis.

\subsection{Number of Leaves andLleaflets}

The number of leaves decreased as the cadmium doses increased; however, there were statistically significant differences only when treatments $\mathrm{T} 4(534 \mu \mathrm{M})$ and $\mathrm{T} 5(712 \mu \mathrm{M})$ were compared to the control plants. The relative percentage decrease and increase (PRA) value was $-21.58 \%$, which showed decrease in this growth variable due to cadmium toxicity.

Paricá plants presented symptoms such as chlorosis in the older leaves, leaf abscission and epithelia during the cadmium-stress period adopted in the current study. These negative effects significantly changed the photosynthesis and other physiological functions of the herein investigated plant species. Metal ions can be incorporated in proteins or translocated through the phloem of leaves, along with photo-assimilators, and lead to a series of phytotoxicities (Azevedo et al., 2012; Gallego et al., 2012).

The number of leaflets decreased until T3 $(356 \mu \mathrm{M})$, increased in T4 $(534 \mu \mathrm{M})$, and decreased again in T5 $(712$ $\mu \mathrm{M})$; RPDI value was $-26.63 \%$ - it was the highest value recorded for growth parameters, which showed that this organ is one of the most affected by cadmium toxicity (Table 1).

Table 1. Analysis of variance and regression equations applied to shoot and root growth and physiological parameters in Schizolobium amazonocum Huber ex Ducke seedlings subjected to increasing cadmium doses for 14 days and their respective relative percentage decrease and increase (RPDI) values

\begin{tabular}{|c|c|c|c|c|c|c|c|c|c|}
\hline \multirow{2}{*}{ Parameter } & \multicolumn{5}{|c|}{ Cadmium doses $(\mu \mathrm{M})$} & \multirow{2}{*}{$\begin{array}{l}\text { CV } \\
(\%)\end{array}$} & \multirow{2}{*}{$\begin{array}{l}\text { RPDI } \\
(\%)\end{array}$} & \multirow{2}{*}{ Regression equation } & \multirow{2}{*}{$\mathbf{R}^{2}(\%)$} \\
\hline & $\mathbf{0}$ & 178 & 356 & 534 & 712 & & & & \\
\hline Plant height $(\mathrm{cm})$ & $43.41 \mathrm{a}$ & $36.96 \mathrm{~b}$ & $34.20 \mathrm{~b}$ & $34.69 \mathrm{~b}$ & $37.26 \mathrm{~b}$ & 9.32 & -14.17 & $\mathrm{y}=43.2591-0.0424 \mathrm{x}+4.8 \mathrm{E}-5 \mathrm{x}^{2 * *}$ & 99.51 \\
\hline Collar diameter (mm) & $8.45 \mathrm{a}$ & $6.80 \mathrm{~b}$ & $6.77 \mathrm{~b}$ & $6.99 \mathrm{~b}$ & $7.24 \mathrm{ab}$ & 12.01 & -14.41 & $y=8.2769-0.0078 x+9.1175 E-6 x^{2 * *}$ & 85.73 \\
\hline N. of leaves & $7.83 \mathrm{a}$ & $7.00 \mathrm{ab}$ & $7.00 \mathrm{ab}$ & $6.29 \mathrm{~b}$ & $6.14 \mathrm{~b}$ & 11.02 & -21.58 & $y=7.6714-0.0023 x^{* *}$ & 91.63 \\
\hline N. of leaflets & $36.71 \mathrm{a}$ & $27.86 \mathrm{ab}$ & $24.50 \mathrm{~b}$ & $28.57 \mathrm{ab}$ & $26.57 \mathrm{~b}$ & 22.58 & -27.63 & $\mathrm{y}=35.7776-0.0449 x+4.7665 \mathrm{E}-5 \mathrm{x}^{2 *}$ & 80.71 \\
\hline Chlorophyll a $\left(\mathrm{mmol} \mathrm{kg}^{-1} \mathrm{FM}\right)$ & $2.89 \mathrm{a}$ & $1.29 \mathrm{bc}$ & $0.22 \mathrm{c}$ & $1.33 \mathrm{~b}$ & $1.92 \mathrm{~b}$ & 47.64 & -33.40 & $\mathrm{y}=2.8457-0.0116 \mathrm{x}+1.483 \mathrm{E}-5 \mathrm{x}^{2 * *}$ & 89.97 \\
\hline Chlorophyll $b\left(\mathrm{mmol} \mathrm{kg}^{-1} \mathrm{FM}\right)$ & $10.89 \mathrm{a}$ & $6.85 \mathrm{~b}$ & $4.66 \mathrm{~b}$ & $6.32 \mathrm{~b}$ & $6.83 \mathrm{~b}$ & 24.37 & -37.26 & $y=10.6938-0.0257 x+2.9225 E-5 x^{2 * *}$ & 92.43 \\
\hline Total chlorophyll (mmol kg $\left.{ }^{-1} \mathrm{FM}\right)$ & $13.78 \mathrm{a}$ & $7.49 \mathrm{bc}$ & $5.16 \mathrm{c}$ & $7.65 \mathrm{bc}$ & $8.76 \mathrm{~b}$ & 22.78 & -36.45 & $y=13.883-0.0585 x+0.0001 x^{2}-7.8885 E-8 x^{3 *}$ & 98.24 \\
\hline Anthocyanin (mg $100 \mathrm{~g}^{-1}$ ) & $0.0047 \mathrm{a}$ & $0.0029 \mathrm{bc}$ & $0.0015 \mathrm{c}$ & $0.0024 \mathrm{bc}$ & $0.0036 \mathrm{ab}$ & 32.64 & -24.51 & $\mathrm{y}=0.0047-1.4829 \mathrm{E}-5 \mathrm{x}+1.8663 \mathrm{E}-8 \mathrm{x}^{2 * *}$ & 96.18 \\
\hline$A\left(\mu \mathrm{mol} \mathrm{m} \mathrm{m}^{-2} \mathrm{~s}^{-1}\right)$ & $7.36 \mathrm{a}$ & $5.06 \mathrm{~b}$ & $3.92 \mathrm{c}$ & $1.62 \mathrm{~d}$ & $1.76 \mathrm{~d}$ & 9.85 & -76.11 & $y=7.4047-0.0142 x+8.3644 E-6 x^{2 * *}$ & 97.12 \\
\hline $\mathrm{gs}\left(\mathrm{mmol} \mathrm{m} \mathrm{s}^{-2}\right)$ & $0.16 \mathrm{a}$ & $0.17 \mathrm{a}$ & $0.13 \mathrm{~b}$ & $0.04 \mathrm{c}$ & $0.04 \mathrm{c}$ & 7.54 & -74.53 & $\mathrm{y}=0.1564+0.0004 \mathrm{x}-2.2058 \mathrm{E}-6 \mathrm{x}^{2}+1.9235 \mathrm{E}-9 \mathrm{x}^{3 * *}$ & 98.90 \\
\hline$E\left(\mathrm{mmol} \mathrm{m}^{-2} \mathrm{~s}^{-1}\right)$ & $2.33 \mathrm{a}$ & $2.56 \mathrm{a}$ & $1.90 \mathrm{ab}$ & $1.26 \mathrm{bc}$ & $1.05 \mathrm{c}$ & 13.86 & -54.75 & $\mathrm{y}=2.3325+0.0046 \mathrm{x}-2.3116 \mathrm{E}-5 \mathrm{x}^{2}+1.9812 \mathrm{E}-8 \mathrm{x}^{3 *}$ & 99.81 \\
\hline $\mathrm{Ci} / \mathrm{Ca}\left(\mathrm{mol} \mathrm{mol}^{-1}\right)$ & $0.79 \mathrm{~b}$ & $0.87 \mathrm{a}$ & $0.80 \mathrm{~b}$ & $0.62 \mathrm{c}$ & $0.77 \mathrm{~b}$ & 11.87 & -2.05 & $y=0.7809+0.0017 x-7.4323 E-6 x^{2}+7.0045 E-9 x^{3 * *}$ & 93.07 \\
\hline $\operatorname{iCE}\left[\left(\mu \mathrm{mol} \mathrm{m}^{-2} \mathrm{~s}^{-1}\right)\left(\mu \mathrm{mol} \mathrm{mol}^{-1}\right)^{-1}\right]$ & $0.02 \mathrm{a}$ & $0.01 \mathrm{~b}$ & $0.01 \mathrm{~b}$ & $0.01 \mathrm{c}$ & $0.01 \mathrm{c}$ & 13.21 & -76.66 & $y=0.023-4.0835 E-5 x+2.3321 E-8 x^{2 *}$ & 97.30 \\
\hline WUE $\left[\left(\mu \mathrm{mol} \mathrm{m}^{-2} \mathrm{~s}^{-1}\right)\left(\mathrm{mmol} \mathrm{H}_{2} \mathrm{O} \mathrm{m}^{-2} \mathrm{~s}^{-1}\right)^{-1}\right]$ & $3.17 \mathrm{a}$ & $1.98 \mathrm{~b}$ & $2.05 \mathrm{~b}$ & $1.16 \mathrm{c}$ & $1.73 \mathrm{~b}$ & 10.39 & -45.30 & $\mathrm{y}=3.1194-0.0062 \mathrm{x}+5.7672 \mathrm{E}-6 \mathrm{x}^{2 * *}$ & 85.26 \\
\hline iWUE $\left[\left(\mu \mathrm{mol} \mathrm{m}^{-2} \mathrm{~s}^{-1}\right)\left(\mathrm{mmol} \mathrm{m}^{-2} \mathrm{~s}^{-1}\right)\right]$ & $46.63 \mathrm{a}$ & $30.24 \mathrm{~b}$ & $31.25 \mathrm{ab}$ & $37.81 \mathrm{ab}$ & $45.23 \mathrm{ab}$ & 15.10 & -2.99 & $\mathrm{y}=44.8699-0.0827 \mathrm{x}+0.0001 \mathrm{x}^{2 * *}$ & 87.91 \\
\hline
\end{tabular}




\section{Conclusion}

The paricá plants were sensible to the cadmium dosages interfering in the gas exchange and growth.

Regarding the physiological parameters they did not support the applied cadmium doses, altering their energy production in the form of ATP and NADPH.

It took 14 days for the cadmium doses to alter all growth and physiological parameters. However, the variable intrinsic efficiency of water use (EiUA) was elevated in the stress conditions maintaining the minimum of water balance.

The phytotoxic element cadmium was mainly concentrated in the roots, but there was translocation to shoot, signaling a phytoextractive characteristic.

\section{References}

Almeida, L. G. (2015). Parâmetros de crescimento, bioquímicos e ecofisiológicos em plantas de milho cultivadas em solos multicontaminados com Cd e Zn (p. 83, Dissertação (Mestrado), Universidade Federal de Lavras/MG).

Azevedo, R. A., Gratão, P. L., Monteiro, C. C., \& Carvalho, R. F. (2012). What is new in the research on cadmium-induced stress in plants? Food \& Energy Security, 1(2). 133-140. https://doi.org/10.1002/fes3.10

Bacelar, E. A., Moutinho-Pereira, J. M., Gonçalves, B. C., Ferreira, H. F., \& Correia, C. M. (2007). Changes in growth, gas exchange, xylem hydraulic properties and water use efficiency of three olive cultivars under contrasting water availability regimes. Environmental and Experimental Botany, 60(2), 183-192. https://doi.org/10.1016/j.envexpbot.2006.10.003

Benavides, M. P., Gallego, S. M., \& Tomaro, M. L. (2005). Cadmium toxicity in plants. Brazilian Journal of Plant Physiology, 17(1), 21-34. https://doi.org/10.1590/S1677-04202005000100003

DalCorso, G., Farinati, S., Maistri, S., \& Furini, A. (2008). How plants cope with cadmium: Staking all on metabolism and gene expression. Integrative Plant Biology, 50(10), 1268-1280. https://doi.org/10.1111/j. 1744-7909.2008.00737.x

Ekmekçia, Y., Tanyolaçb, D., \& Ayhana, B. (2008). Effects of cadmium on antioxidant enzyme and photosynthetic activities in leaves of two maize cultivars. Jounal Plant Physiology, 165(6), 600-611. https://doi.org/10.1016/j.jplph.2007.01.017

Ferreira, D. F. (2011). Sisvar: A computer statistical analysis system. Ciência e Agrotecnologia, 35(6), 1039-1042. https://doi.org/10.1590/S1413-70542011000600001

Ferreira, M. M. A. A. S. (2013). Toxidez de cádmio inibe o crescimento e altera a absorção de nutrientes do girasol (p. 45, Dissertação (Mestrado em Ciências Agrarias, Ambientais e Biológicas), Universidade Federal do Recôncavo da Bahia, Cruz das Almas, BA).

Fornazier, R. F., Ferreira, R. R., Vitória, A. P., Molina, S. M. G., \& Lea, P. J. (2002). Effects of cadmium on antioxidant enzymes activities in sugar cane. Biologia Plantarum, 45(1), 91-97. https://doi.org/10.1023/ A: 1015100624229

François, M., Grant, C., Lambert, R., \& Sauvé, S. (2009). Prediction of cadmium and zinc concentration in wheat grain from soils affected by the application of phosphate fertilizers varying in $\mathrm{Cd}$ concentration. Nutrientes Ciclagem em Agroecossistema, 83(2), 125-133. https://doi.org/10.1007/s10705-008-9204-0

Gallego, S. M., Liliana, B. P., Roberto, A. B., Claudia, E. A., María, F. I., Eliana, P. R., ... María, P. B. (2012). Unravelling cadmium toxicity and tolerance in plants: Insight into regulatory mechanisms. Environmental and Experimental Botany, 83, 33-46. https://doi.org/10.1016/j.envexpbot.2012.04.006

Grant, C. A. (2010). Influence of Phosphate Fertilizer on Cadmium in Agricultural Soils and Crops. Pedologist, 54(3), 143-155.

Guerra, A. M. N. M., Rodrigues, F. Á., Lima, T. C., Berger, P. G., Barros, A. F., \& Silva, Y. C. R. (2014). Capacidade fotossintética de plantas de algodoeiro infectadas por ramulose e supridas com silício. Bragantia, Campinas, 73(1), 50-64. https://doi.org/10.1590/brag.2014.010

Hasanuzzaman, M., Nahar, K., Alam, M. M., \& Fujita, M. (2013). In M. Hasanuzzaman, \& M. Fujita (Eds.), Adverse Effects of Cadmium on Plants and Possible Mitigation of Cadmium-Induced Phytotoxicity Capitulo 1 em Cadmium: Characteristics, Sources of Exposure, Health and Environmental Effects (pp. 1-48). Nova Science Publishers, Inc., Nova Iorque, EUA. 
Keilig, K., \& Ludwig-Mül, J. (2009). Effect of flavonoids on heavy metal tolerance in Arabidopsis thaliana seedlings. Botanical Studies, 50(3), 311-318.

Knecht, J. A., Van Dillen, M., Koevoets, P. L. M., Schat, H., Verkleij, J. A. C., \& Ernst, W. H (1994). Phytochelatins in cadmium-sensitive and cadmium-tolerant Silene vulgaris. Plant Physiology, 104, $255-261$. https://doi.org/10.1104/pp.104.1.255

Lefèvre, I., Vogel - Mikus, K., Jeromel, L., Vavpetic, P., Planchon, S., Arčon, I., ... Lutts, S. (2014). Differential cadmium and zinc distribution in relation to their physiological impact in the leaves of the accumulating Zygophyllum fabago L. Plant, Cell and Environment, 37(6). 1299-1320. https://doi.org/10.1111/pce.12234

Leita, L., Marchiol, L., Martin, M., Peressotti, A., Delle Vedove, G., \& Zerbi, G. (1995). Transpiration dynamics in cadmium-treated soybean (Glycine max L.) plants. Journal Agronomy Crop Science, 175(3), $153-156$. https://doi.org/10.1111/j.1439-037X.1995.tb00206.x

Ma, C. C., Gao, Y. B., Guo, H. Y., \& Wang, J. L. (2004). Photosynthesis, transpiration and water use efficiency of Caragana microphylla, C. intermedia and C. korshinskii. Photosynthetica, 42(1), 65-70. https://doi.org/ 10.1023/B:PHOT.0000040571.63254.c2

Marques, M. C., \& Nascimento, C. W. A. (2013). Analysis of chlorophyll fluorescence spectra for the monitoring of Cd toxicity in a bio-energy crop (Jatropha curcas). Photochemistry and Photobiology B: Biology, 127, 88-93. https://doi.org/10.1016/j.jphotobiol.2013.07.016

Martins, L. L., Reis, R., Moreira, I., Pinto, F., Sales, J., \& Mourato, M. (2013). Antioxidative Response of plants to oxidative stress induced by cadmium. In M. Hasanuzzaman, \& M. Fujita (Eds.), Capitulo 3, em Cadmium: Characteristics, Sources of Exposure, Health and Environmental Effects. Nova Science Publishers, Inc., Nova Iorque, EUA.

Michalak, A. (2006). Phenolic compounds and their antioxidant activity in plants growing under heavy metal stress. Polish Journal of Environmental Studies, 15(4), 523-530.

Ok, Y. S., Kim, S. C., Kim, D. K., Skousen, J. G., Lee, J. S., Cheong, Y. W., .. Yang, J. E. (2011). Ameliorants to immobilize $\mathrm{Cd}$ in rice paddy soils contaminated by abandoned metal mines in Korea. Environmental Geochemistry and Health, 33(1), 23-30. https://doi.org/10.1007/s10653-010-9364-0

Parmar, S., Stuiver, C. E. E., Posthumus, F. S., \& Shahbaz, M. (2014). Zinc exposure has differential effects on uptake and metabolism of sulfur and nitrogen in Chinese cabbage. Journal of Plant Nutrition and Soil Science, 177(5), 748-757. https://doi.org/10.1002/jpln.201300369

Perfus-Barbeoch, L., Leonhardt, N., Vavasseur, A., \& Forestier, C. (2002). Heavy metal toxicity: Cadmium permeates through calcium channels and disturbs the plant water status. The Plant Journal, 32(4), 539-548. https://doi.org/10.1046/j.1365-313X.2002.01442.x

Qian, H., Li, J., Pan-X., Jiang, H., Sun, G., \& Fu, Z. (2010). Photoperiod and temperature influence cadmium's effects on photosynthesis-related gene transcription in Chlorella vulgaris. Ecotoxicology and Environmental Safety, 73(6), 1202-1206. https://doi.org/10.1016/j.ecoenv.2010.07.006

Redondo-Gómez, S., Mateos-Naranjo, E., \& Andrades-Moreno, L. (2010). Accumulation and tolerance characteristics of cadmium in a halophytic Cd-hyperaccumulator, Arthrocnemum macrostachyum. Hazardous Materials, 184(1-3), 299-307. https://doi.org/10.1016/j.jhazmat.2010.08.036

Römkens, P. F. A. M., Brus, D. J., Guo, H. Y., Chu, C. L., Chiang, C. M., \& Koopmans, G. F. (2011). Impact of model uncertainty on soil quality standards for cadmium in rice paddy fields. Sci. Total Environ., 409, 3098-3105. https://doi.org/10.1016/j.scitotenv.2011.04.045

Roychoudhury, A., Basu, S., \& Sengupta, D. N. (2012). Antioxidants and stress-related metabolites in the seedlings of two indica rice varieties exposed to cadmium chloride toxicity. Acta Physiol Plant, 34(17), 835-847. https://doi.org/10.1016/j.scitotenv.2011.04.045

Sarruge, J. R. (1975). Soluções nutritivas. Summa Phytopathologica, 1(3), 231-233.

Shah, K., Kumar, R. G., Verma, S., \& Dubey, R. S. (2001). Effect of cadmium on lipid peroxidation, superoxide anion generation and activities of antioxidant enzymes in growing rice seedlings. Plant Science, 161(6), 1135-1144. https://doi.org/10.1016/S0168-9452(01)00517-9

Sims, D. A., \& Gamon, J. A. (2002). Relationships between leaf pigment content and spectral reflectance across a wide range of species, leaf structures and developmental stages. Remote Sensing of Environment, 81(2-3), 337-354. https://doi.org/10.1016/S0034-4257(02)00010-X 
Singh, H. P., Mahajan, P., Kaur, S., Daizy, R. B., \& Kohli, R. K. (2013). Chromium toxicity and tolerance in plants. Environmental Chemistry Letters, 11(3), 229-254. https://doi.org/10.1007/s10311-013-0407-5

Soltan, M. E., \& Rashed, M. N. (2003). Laboratory study on the survival of water hyacinth under several conditions of heavy metal concentrations. Advances in Environmental Research, 7(2), 321-334. https://doi.org/10.1016/S1093-0191(02)00002-3

Souza, E. P., Silva, I. F., \& Ferreira, L. E. (2011). Mecanismos de tolerância a estresses por metais pesados em plantas. Revista Brasileira. Agrociência, 17(2-4), 167-173.

Taiz, L., \& Zeiger, E. (2002a). Plant Physiology (3rd ed.). Sinaeur, Sunderland, EUA.

Taiz, L., \& Zeiger, E. (2009b). Fisiologia Vegetal (4th ed., p. 848). Porto Alegre: Artemed.

Taiz, L., \& Zeiger, E. (2013c). Fisiologia Vegetal (5th ed., p. 719). Porto Alegre: Artmed.

Vitória, A. P., Lea, P. J., \& Azevedo, R. A. (2001). Antioxidant enzymes responses to cadmium in radish tissues. Phytochemistry, 57(5), 710-715. https://doi.org/10.1016/S0031-9422(01)00130-3

Zhang, G.-B., Yi, H.-Y., \& Gong, J.-M., (2014). The Arabidopsis Ethylene/jasmonic acid-NRT signaling module coordinates nitrate reallocation and the trade-off between growth and environmental adaptation. Plant Cell, 26(10), 3984-3998. https://doi:10.1105/tpc.114.129296

Zhao, B., Kondo, M., Maeda, M., Ozaki, Y., \& Zhang, J. (2004). Water-use efficiency and carbono isotop discrimination in two cultivars of upland rice durong diferente developmental stages under three water regimes. Plant and Soil, 261(1-2), 61-75. https://doi.org/10.1023/B:PLSO.0000035562.79099.55

\section{Copyrights}

Copyright for this article is retained by the author(s), with first publication rights granted to the journal.

This is an open-access article distributed under the terms and conditions of the Creative Commons Attribution license (http://creativecommons.org/licenses/by/4.0/). 